\title{
Development of biodegradable smart packaging from chitosan, polyvinyl alcohol (PVA) and butterfly pea flower's (Clitoria ternatea L.) anthocyanin extract
}

\author{
Hidayati, N.A., Wijaya, M.W., Bintoro, V.P., "Mulyani, S. and Pratama, Y. \\ Department of Food Technology, Faculty of Animal and Agricultural Sciences, Diponegoro University, Jl. \\ Prof. Soedarto, Tembalang, Semarang, 50275, Indonesia
}

\begin{abstract}
Article history:
Received: 26 September 2020 Received in revised form: 20 November 2020

Accepted: 2 February 2021 Available Online: 13 June 2021
\end{abstract}

\section{Keywords:}

Anthocyanin,

Chitosan,

Clitoria ternatea L.,

PVA,

Smart packaging

DOI:

https://doi.org/10.26656/fr.2017.5(3).537

\begin{abstract}
Active compounds from natural sources such as butterfly pea flowers (Clitoria ternatea L.) such as anthocyanin was found able to be integrated with chitosan and Polyvinyl Alcohol (PVA) polymers in their application as smart packaging. Smart packaging that contains anthocyanin shows a colour response to changes in $\mathrm{pH}$ due to food spoilage. This study was aimed to evaluate the effects of chitosan $(\mathrm{CH})$ and PVA proportion on the quality of biodegradable film incorporating butterfly pea flower's anthocyanin (BPFA) extract included film thickness, tensile strength (TS), elongation (E\%), total anthocyanin content and the film colour response at different $\mathrm{pH}$ range were characterized. Concentrated anthocyanin extract was obtained from butterfly pea flower petals in ultrasonic-assisted leaching using ethanol as a solvent and followed by rotary vacuum evaporation. The film-forming solution was prepared from a binary mixture of CH:PVA in the ratio of 20:80, 40:60, 60:40, and 80:20. The results showed that films obtained from all combinations could exhibit different colour responses in various $\mathrm{pH}$ ranges, indicating the successful incorporation of anthocyanin. The film with CH:PVA ratio of 40:60 showed a more pronounced colour change, among other treatments. It was also characterized by a thickness of $0.15 \mathrm{~mm}$, TS of $11.02 \mathrm{MPa}, \mathrm{E} \%$ of $48.00 \%$, and total anthocyanin of $25.08 \mathrm{mg} / \mathrm{g}$. The film showed high potential to be used as biodegradable smart packaging for the food system which produces $\mathrm{pH}$ change upon deterioration.
\end{abstract}

\section{Introduction}

Efforts to maintain food availability are carried out by ensuring safety and reducing post-harvest loss. This system is applied to a variety of food commodities by providing packaging that has function as a protector, product container, has eased distribution, and communication. Based on these basic functions, a breakthrough is made in the form of smart packaging as an indicator of changes that lead to food spoilage (Kuswandi et al., 2011). Spoilage of bacteria on food causes damage by impacting changes in food $\mathrm{pH}$. Smart packaging with the addition of active compounds can detect changes in food $\mathrm{pH}$ through a colour response due to reactions with volatile amines produced by bacteria (Wei et al., 2017).

The $\mathrm{pH}$ sensing natural dye that is commonly used is anthocyanin due to its colour producing response relating to $\mathrm{pH}$ changes, the presence of other colours, temperature, the concentration of other substances, certain chemical structures, oxygen, solvents, light exposure, the presence of enzymes and metal ions (Yoshida et al., 2014). Anthocyanin can produce a variety of colours such as red, purple, dark blue, or dark red. It is responsible for colours in some fruits, vegetables and flowers including the butterfly pea flower (Clitoria ternatea L.). Anthocyanin extracts from butterfly pea flowers have characteristic similarities to anthocyanins, which are easily soluble in water, nontoxic, yet easily damage in high temperatures. Those characteristics are suitable for anthocyanin to be immobilized in making smart packaging or biodegradable films (Choi et al., 2017).

Indicators film for food must be made from foodgrade materials, including chitosan $(\mathrm{CH})$, tapioca, agarose, PVA, and others. $\mathrm{CH}$ is a polymer that can produce a strong film, biodegradable, edible, and has good antibacterial properties. $\mathrm{CH}$ has good emulsifying activity and is thus often combined with other material/ polymer to improve its film properties, for instance, with 
hydrophobic substances like palm olein to improve its water vapour barrier (Pratama et al., 2019). Whilst another polymer such as PVA can be used to improve the film mechanical features. Combining $\mathrm{CH}$ and PVA into a blended film has already been done in a previous study conducted by El-Hefian et al. (2010) and Bonilla et al. (2014). CH-PVA film that combined in various proportions, showed the difference in physical, structural, and antimicrobial properties. Moreover, $\mathrm{CH}-$ PVA film can be incorporated with a bioactive compound such as anthocyanin extract which functions as a natural $\mathrm{pH}$ sensing dye.

According to a previous study by Pereira et al. (2015), CH-PVA film can be immobilized with anthocyanin contain in red cabbage. However, based on that study, anthocyanin from red cabbage couldn't show pronounced colour changes in various $\mathrm{pH}$ ranges. Therefore, in this study, another source of anthocyanin, such as Clitoria ternatea L., contains a dense and high concentration of anthocyanin. Clitoria ternatea L. produced more stable anthocyanin compare to other sources (Chu et al., 2016). Clitoria ternatea L. is a native plant from Asia and can be found easily in Indonesia. The colour of anthocyanin extracted from Clitoria ternatea L. tends to have higher stability as long as it is kept away from direct contact with light at low room temperature, allowing it to be applied as a $\mathrm{pH}$ change indicator (Saptarini et al., 2015).

This study discussed the proportion of $\mathrm{CH}$ and PVA effect on the quality of indicators film containing anthocyanin from butterfly pea flower (Clitoria ternatea L.) including film thickness, TS, E\%, the colour response of film and total anthocyanin content of film indicator. This study was aimed to determine the right proportion of $\mathrm{CH}$ and PVA to produce an indicator film for food $\mathrm{pH}$ changes.

\section{Materials and methods}

\subsection{Materials}

Chitosan (CH), Polyvinyl Alcohol (PVA), butterfly pea flower (Clitoria ternatea L.), acetic acid, ethanol $96 \%$, glycerol, $\mathrm{HCl}$, and aquadest.

\subsection{Extraction of anthocyanins from butterfly pea flower}

Butterfly Pea Flower Anthocyanin (BPFA) was extracted according to Damodaran et al. (2018) and was based on previous work (unpublished data). Fresh butterfly pea flower petals were washed and crushed. The material was dissolved in solvent $96 \%$ ethanol in an Erlenmeyer flask with a solid to solvent ratio of 1:10. The sample was extracted sonically (Branson 2510,
United States) for 15 mins with a depth of $2 \mathrm{~cm}$. The extract was filtered on filter paper. The filtrate was concentrated in a vacuum rotary evaporator (Biobase RE -2000A and SHZ-D (III) Water Aspirator, China) until equilibrium was reached. The resulting concentrate was stored in an opaque glass bottle coated with aluminium foil at $6^{\circ} \mathrm{C}$

\subsection{Film preparation}

The films were made according to El-Hefian et al. (2010) with slight modification. Chitosan solution of $2 \%$ (w/v) was prepared by dissolving $2 \mathrm{~g}$ of $\mathrm{CH}$ in $100 \mathrm{~mL}$ $1 \%(\mathrm{v} / \mathrm{v})$ acetic acid under 4 speed stirring at $130^{\circ} \mathrm{C}$ for 30 mins with a magnetic stirrer (Ika T25 Digital UltraTurrax, China). PVA solution of $2.3 \%(\mathrm{w} / \mathrm{v})$ was prepared by dissolving $2.3 \mathrm{~g}$ of PVA in $100 \mathrm{~mL}$ distilled water $(\mathrm{v} / \mathrm{v})$ under 4 speed stirring at $130^{\circ} \mathrm{C}$ for 90 mins. The two solutions were mixed according to the proportion of CH:PVA (20:80, 40:60, 60:40 and 80:20) for 5 mins, then the glycerol $1 \%(\mathrm{v} / \mathrm{v})$ was added as the plasticizer under constant stirring for 10 mins. The film hydrogel was spread $(100 \mathrm{~mL})$ in a Teflon pan and was then was placed in an oven (Memmert, Germany) at $80^{\circ} \mathrm{C}$ for $5 \mathrm{hrs}$

\subsection{Immobilization of anthocyanin extract from butterfly pea flower}

Immobilization of Butterfly Pea Flower Anthocyanin (BPFA), according to Warsiki et al. (2013) with slight modification. BPFA of $1 \mathrm{~mL}$ natural $\mathrm{pH}$ sensing dye was smeared on a $40 \mathrm{~cm}^{2}$ film surface using a cake brush. The BPFA application was done gradually to make sure the colour was applied evenly.

\subsection{Film thickness}

The film thickness was measured according to Pereira et al. (2015), by using a micrometre screw (Herma, Germany) on five different spots. The reported value is the average of the thickness taken randomly for each sample.

\subsection{Tensile strength and elongation at break}

The tensile strength (TS) of the film according to Saxena et al. (2009), films were cut into $1 \times 5 \mathrm{~cm}$ pieces, respectively. The elongation at break $(\mathrm{E} \%)$ of the film was carried out according to Jirukkakul (2013) with slight modification. The films were cut into $3 \times 3 \mathrm{~cm}$, respectively. The pieces were fixed into tensile grips on a texture analyser (Brookfield CT-3, United States). The following equation was used in calculating the TS and $\mathrm{E} \%$ :

$$
\operatorname{TS} \sigma(\mathrm{MPa})=\frac{\mathrm{F}(\mathrm{N})}{\mathrm{A}\left(\mathrm{m}^{2}\right)}
$$


$\mathrm{E} \%=\frac{\text { final length }- \text { initial length }}{\text { initial length }} \times 100 \%$

\subsection{Total anthocyanin content}

Total anthocyanin content in the film was measured using the $\mathrm{pH}$ differential method. Indicator films were cut into $4 \mathrm{~cm}^{2}$ for each solvent. The cut film was submerged in the blank solvent $1 \mathrm{~mL} \mathrm{KCl}$ buffer $\mathrm{pH} 1$ and $1 \mathrm{~mL}$ sodium acetate buffer $4.5 \mathrm{pH}$, respectively. Both solvents were settled for 30 mins of operating time. The total anthocyanin absorbance was measured using a UV-Vis spectrophotometer (Shimadzu, Japan) at $520 \mathrm{~nm}$ and $700 \mathrm{~nm}$ wavelengths. The absorbance of the samples was determined by the following equation:

$\mathrm{A}=\left(\mathrm{A}_{520}-\mathrm{A}_{700}\right)_{\mathrm{pH} 1}-\left(\mathrm{A}_{520}-\mathrm{A}_{700}\right)_{\mathrm{pH} 4.5}$

Total anthocyanin content was determined by the following equation according to Luchese et al. (2017):

$$
\text { Anthocyanin }(\mathrm{mg} / \mathrm{g})=\frac{\mathrm{A} \times \mathrm{MW} \times \mathrm{FP} \times \mathrm{V}}{\varepsilon \times \mathrm{L}} \times 100
$$

Whereby, A represents the absorbance value, MW is the molecular weight of predominant anthocyanin cyanidin 3-glucoside $=449.2(\mathrm{~g} / \mathrm{mol}), \mathrm{FD}$ is the dilution factor, " $\varepsilon$ " is the molar absorbance of cyanidin 3glucoside $=26,900$ and $\mathrm{L}$ is the width of the cuvette.

\subsection{Colour change of indicator film in various $\mathrm{pH}$ range}

Indicator films response to various $\mathrm{pH}$ ranges were performed in Koosha and Hamedi (2019) method with modification. The indicator films were cut into $4 \mathrm{~cm}^{2}$ pieces for each seven $\mathrm{pH}$ buffer solutions. The samples were placed in a petri dish, and then $1 \mathrm{~mL}$ of buffer solution $\mathrm{pH}$ 1, $\mathrm{pH} 3, \mathrm{pH} 5, \mathrm{pH}$ 7, pH 9, pH 11 and $\mathrm{pH} 13$ were dropped, respectively. The film images were captured in a light-controlled environment with a digital camera. The colour intensities were expressed in Red, Green, and Blue (RGB) values using Colour Grab version 3.6.1. Grayscale Index $\left(\mathrm{I}_{\mathrm{G}}\right)$, where the lower value indicates more pronounced colour intensity.

\subsection{Data analysis}

The film colour response was analysed descriptively. While, film thickness, tensile strength, elongation at break, and total anthocyanin content were statistically analysed using the Analysis of Variance (ANOVA) test with a significance level of 5\%. Then proceed with the Duncan test to find out the differences between each treatment.

\section{Results and discussion}

\subsection{Film thickness}

The average thickness of the $\mathrm{CH}-\mathrm{PVA}$ film ranged between 0.12 to $0.16 \mathrm{~mm}$ (Table 1). Based on ANOVA with a significance level of $\mathrm{p}<0.05$, there was no influence of $\mathrm{CH}$ and PVA proportion on film thickness. Based on the Duncan test it was found that there were no significant differences among the film treatments. Based on Table 1, it can be seen that the variation of $\mathrm{CH}$ and PVA proportion does not affect film thickness. The increase of PVA addition was affecting the increase of the film thickness. This is due to PVA in the form of a polymer solution that has a high viscosity. When the $\mathrm{CH}$ and PVA were combined into one polymer solution, PVA played a role in influencing the viscosity of the mixture (Bonilla et al., 2014).

The film thickness was related to the film degradation rate. The degradation rate of the film was influenced by several factors, including the characteristics of the material used and the thickness of the film (Gomes et al., 2011). PVA increases the film thickness due to its hydrophilic properties. PVA as the hydrophilic polymer increases the film water binding capacity and the film thickness. The film thickness also improves the mechanical properties of the film, light transmission, and WVP. Based on a previous study by Wang et al. (2019), black soybean seed coat extract as a $\mathrm{pH}$ sensing dye does not affect the thickness of the chitosan film.

\subsection{Tensile strength}

The average calculation of the TS of CH-PVA films ranged from 3.1-13.18 $\mathrm{MPa}$ (Table 1). Based on ANOVA with the significance level of $\mathrm{p}<0.05$ it was shown that there was an effect of the proportion of $\mathrm{CH}$ and PVA on the tensile strength of the film. Based on Duncan's test it was found that there were significant differences in each treatment. As shown in Table 1 it is known that the increase in the PVA ratio was affecting the increase in tensile strength. Otherwise, a higher $\mathrm{CH}$

Table 1. Solubility, tensile strength and total anthocyanin content of indicator film with various proportion of CH and PVA with the addition of BPFA Extract

\begin{tabular}{ccccc}
\hline Proportion & Thickness $(\mathrm{mm})$ & Tensile Strength & Elongation & Total Anthocyanin \\
\hline T1 $(20: 80)$ & $0.16 \pm 0.06^{\mathrm{a}}$ & $13.18 \pm 1.17^{\mathrm{a}}$ & $50.00 \pm 0.00^{\mathrm{a}}$ & $13.87 \pm 1.13^{\mathrm{d}}$ \\
T2 $(40: 60)$ & $0.15 \pm 0.04^{\mathrm{a}}$ & $11.02 \pm 1.06^{\mathrm{b}}$ & $48.00 \pm 2.55^{\mathrm{a}}$ & $25.08 \pm 2.63^{\mathrm{b}}$ \\
T3 $(60: 40)$ & $0.13 \pm 0.05^{\mathrm{a}}$ & $5.0 \pm 0.73^{\mathrm{c}}$ & $15.80 \pm 4.66^{\mathrm{b}}$ & $17.45 \pm 1.62^{\mathrm{c}}$ \\
T4 $(80: 20)$ & $0.12 \pm 0.03^{\mathrm{a}}$ & $3.1 \pm 0.25^{\mathrm{d}}$ & $10.80 \pm 3.11^{\mathrm{c}}$ & $26.81 \pm 2.10^{\mathrm{a}}$ \\
\hline
\end{tabular}

Value with different superscript in the same column indicates the significant difference $(\mathrm{P}<0.05)$. 
ratio added affected the decrease in TS (Hajji et al., 2016). The TS was influenced by the formation of intramolecular and intermolecular bonds that occurred between $\mathrm{CH}$ and PVA. Crosslinking that occurred between $\mathrm{OH}$ groups in PVA and $\mathrm{NH}_{2}$ groups in $\mathrm{CH}$ would increase the tensile strength of films (Abraham et al., 2016; Mittal et al., 2016).

The film CH:PVA (20:80) showed the highest TS of $13.18 \pm 1.17 \mathrm{MPa}$. This showed a similar result with research conducted by Bonilla et al. (2014) whereby the CH-PVA film with a ratio of 20:80 has the highest TS value of $43 \mathrm{MPa}$, compared to the TS of pure chitosan and pure PVA films. TS was needed to determine the mechanical properties of the film. This test could show the strength of the film in resisting the force given. Based on the test of film CH:PVA (40:60), (60:40), and (80:20), it was shown that the decrease in TS was due to the higher ratio of $\mathrm{CH}$ added. $\mathrm{CH}$ was built by the structure of $\mathrm{O}-\mathrm{H}$ and $\mathrm{N}-\mathrm{H}$ which are not flexible and difficult to stretch. Therefore, a higher $\mathrm{CH}$ ratio will decrease the TS of the film (Kurek et al., 2012).

At a certain ratio, $\mathrm{CH}$ and PVA would form a crosslink that could increase the TS of the film. However, the excessive addition of PVA as a plasticizer would cause a decrease in the TS. Film CH:PVA (40:60) and (60:40) showed a decrease in TS compared to film CH:PVA (20:80), whereas film CH:PVA (80:20) had the lowest TS of $3.1 \pm 0.25 \mathrm{MPa}$. The dominant PVA ratio could prevent the formation of crosslinking with $\mathrm{CH}$ that could decrease the film's TS (Munthoub and Rahman, 2011).

\subsection{Elongation at break}

The average of film CH-PVA elongation ranged from 10.8 to $50.0 \%$ (Table 1). Results of ANOVA with the significance of $\mathrm{p}<0.05$ shows that the $\mathrm{CH}$ and PVA proportions were affecting the film $\mathrm{E} \%$. Based on the Duncan test it was found that there were significant differences in each treatment. Based on Table 1, it can be seen that the $\mathrm{E} \%$ was decreasing along with the decrease in the ratio of PVA added.

The film with the highest percentage of $\mathrm{E} \%$ was filmed CH:PVA (20:80) with the E\% of $50.00 \pm 0.00 \%$, followed by film CH:PVA (40:60) with the E\% of $48.00 \pm 2.55 \%$. Based on the Duncan test there were no significant differences between the two treatments. This is due to the amount of PVA that was more dominant compared to chitosan in both film proportions. PVA could increase $\mathrm{E} \%$ as well as increase the tensile strength of the film. PVA was able to form intermolecular reactions with chitosan through hydrogen bonds. In this reaction, the positively charged polysaccharide compound in chitosan moved toward the negatively charged hydroxyl group in PVA (Abraham et al., 2016).

The film CH:PVA (60:40) E\% was $15.80 \pm 4.66 \%$ and film CH:PVA (80:20) E\% was 10.80 $\pm 3.11 \%$. Based on the Duncan test it is known that there were significant differences in the two treatments. The proposition of $\mathrm{CH}$ and PVA in both films were dominated by $\mathrm{CH}$. The higher ratio of $\mathrm{CH}$ in a polymer film was causing a decrease of $\mathrm{E} \%$. Lower $\mathrm{E} \%$ of a film would weaken the film mechanical properties and made the film more brittle with low elasticity (El-Hefian et al., 2010). However, the film CH:PVA (60:40) E\% was higher than the film CH:PVA (80:20). This result was consistent with the research by Ma et al. (2010) about hydroxyethyacryl-chitosan/PVA film with a ratio of 60:40 had an $\mathrm{E} \%$ of $35 \%$, which was higher than films with a ratio of $80: 20$ which has an $\mathrm{E} \%$ of $25 \%$.

\subsection{Total anthocyanin content}

The average total anthocyanin content in the indicator films was in the range of $13.87-26.81 \mathrm{mg} / \mathrm{g}$ (Table 1). Results of ANOVA showed that there was a significant effect of the proportion of $\mathrm{CH}$ and PVA on the total anthocyanin content a significance level of $p<0.05$. Based on the results of Duncan's, it was known that there were significant differences in each film composition. As seen on Table 2 it was known that the highest total anthocyanin content was owned by film CH:PVA (80:20) which is $26.81 \pm 2.10 \mathrm{mg} / \mathrm{g}$, followed by film $\mathrm{CH}:$ PVA (40:60) as the second place which is $25.08 \pm 2.63 \mathrm{mg} / \mathrm{g}$.

The total anthocyanin content in the film is influenced by the amount of BPFA that was absorbed during the immobilization process. $\mathrm{CH}$ ratio could affect the total BPFA that can be immobilized by the film. The effect of $\mathrm{CH}$ was seen in the total anthocyanin content in the film CH:PVA (80:20) and (60:40) which the $\mathrm{CH}$ ratio was higher than the PVA. Immobilization of BPFA could form cross bonds with $\mathrm{CH}$. The phenol group contains in BPFA interacts with the hydroxyl group and the amine group in $\mathrm{CH}$. The phenol group could also react with $\mathrm{CH}$ through electrostatic forces and ester chains (Halász and Csóka, 2018). Based on research conducted by Phrueksanan et al. (2014), butterfly pea flower extract contains a total phenol of $53.00 \pm 0.34 \mathrm{mg}$ gallic acid/g dry extract and flavonoid content of $11.20 \pm 0.33 \mathrm{mg}$ catechin/g dry extract. These results indicated that the phenol content of BPFA had a high probability to conduct interaction with $\mathrm{CH}$.

Based on Table 1 it is known that film CH:PVA (20:80) has the lowest total anthocyanin content in the amount of $13.87 \pm 1.13 \mathrm{mg} / \mathrm{g}$, while the film CH:PVA (40:60) was $25.08 \pm 2.63 \mathrm{mg} / \mathrm{g}$. The proportion of PVA in 
Table 2. Sensitivity test of indicator film with various proportion of $\mathrm{CH}$ and PVA with the addition of BPFA Extract

\begin{tabular}{|c|c|c|c|c|c|c|c|}
\hline \multirow{2}{*}{$\begin{array}{c}\text { CH: PVA } \\
\text { Ratio }\end{array}$} & \multicolumn{7}{|c|}{ Buffer $\mathrm{pH}$} \\
\hline & pH 1 & pH 3 & $\mathrm{pH} 5$ & pH 7 & pH 9 & pH 11 & pH 13 \\
\hline $20: 80$ & & & & & & & \\
\hline $40: 60$ & & & & & & & \\
\hline $60: 40$ & & 9 & & & & & \\
\hline $80: 20$ & & & & & & & \\
\hline
\end{tabular}

those films was higher than $\mathrm{CH}$. This affects the physical properties of the final film polymer becoming stiff and compact. Therefore, BPFA was not perfectly bound to the film when immobilizing by the smearing method on the film's surface. This is due to the PVA hydrophilic properties, while BPFA was extracted in ethanol. Some parts of BPFA were bound due to the interaction of phenol groups with $\mathrm{CH}$ and a small amount of water contained in the BPFA was bonded with PVA. The previous study by Pourjavaher et al. (2017) showed a similar result, in which the red cabbage anthocyanin extract was immobilized in the chitosan-corn starch film polymer. The amount of anthocyanin absorbed was influenced by the morphology of the polymer film. The film's pores were a potential space to be filled by anthocyanin extract.

The film CH:PVA (40:60) has a higher total anthocyanin content than film CH:PVA (20:80) even though both film's composition is dominated by PVA. This is due to the film's CH:PVA (40:60) hydrophilic properties that were stronger. Total anthocyanin content analysis with UV-Vis was influenced by the film waterbinding ability, which in this case is the anthocyanin extract (Halász and Csóka, 2018). The film's CH:PVA (40:60) high total anthocyanin content was induced by the balanced ratio of $\mathrm{CH}$ and PVA that portrayed good BPFA binding properties. In a previous study conducted by Maciel et al. (2015), the pectin-chitosan indicator film (4.3:1) was the best proportion in binding anthocyanin extract powder from grapes due to the optimal reaction of the two polymers.

Total anthocyanin analysis using $\mathrm{pH}$ difference method which includes acidic buffer $\mathrm{pH}$. In a low $\mathrm{pH}$ environment, anthocyanin will occur in the form of flavilium cation which is more stable in giving a clearer colour (Betz et al., 2012). In the buffer pH 1 solvent, the aglycone nucleus of anthocyanin forms a positive oxonium ion called a flavilium cation. Positive oxonium ions will form a double bond chain and turn into pink that can be analysed through visible wavelength. The buffer $\mathrm{pH} 1$ solvent will turn red, which can be analysed in the $520 \mathrm{~nm}$ wavelength (Pereira et al., 2015). In the buffer $\mathrm{pH} 4.5$ solvent, the carbinol form was more dominant than the flavilium cation. The carbinol in anthocyanin does not generate any colour or remain the same as the initial colour. In this case, the colour of the film remained blue or even transparent and was analysed at $700 \mathrm{~nm}$ wavelength. The usage of $700 \mathrm{~nm}$ wavelength was for detecting residues in the solvent (Paes et al., 2014).

The indicator films were showing different colour changes after various $\mathrm{pH}$ buffer was dropped (Table 2). At $\mathrm{pH} 1$ or strong acid buffer, the colour of the film turned pink. At $\mathrm{pH} 3$ and $\mathrm{pH}$, the colour of the film became purple or purplish-blue. At $\mathrm{pH} 7$ the film showed the original colour of BPFA which is blue. At $\mathrm{pH} 9$ and $\mathrm{pH} 11$, the colour of the film turned green. At $\mathrm{pH}$ 13, the colour of the film turned yellow. These colour changes were similar to the previous study by Kang et al. (2018) that the indicator films with anthocyanin mulberries addition turned into purplish-pink to purple at $\mathrm{pH} 2-7$, blue at $\mathrm{pH} \mathrm{8-10,} \mathrm{greenish-blue} \mathrm{at} \mathrm{pH} 11$ and greenishyellow at $\mathrm{pH} 12$ or strong alkali.

The $\mathrm{pH}$ could influence anthocyanin colour changes. Anthocyanins extracted from butterfly pea flower consists of glycosides. Glycosides contain aglycone nuclei, which contain cations of flavilium that produces the red colour in acidic $\mathrm{pH}$. At acidic $\mathrm{pH}(\mathrm{pH}<2)$ the flavilium cation becomes dominant and forms a double bond to produce the colour red (Kungsuwan et al., 2014). A higher $\mathrm{pH}$ will inhibit the production of the red colour and will eventually fade due to the hydrolysis of flavilium cation (Choi et al., 2017). At pH 3-5 a purplish colour was still visible due to the dominant of carbinol. Carbinol does not provide any colour or even prefers to maintain the initial colour of BPFA, especially at neutral $\mathrm{pH}$. At the base $\mathrm{pH}$, the colour changes appeared to be green to yellow.

As shown in Figure 1, it is known that the highest $\mathrm{I}_{\mathrm{G}}$ average was film CH:PVA $(80: 20)$ with $\mathrm{I}_{\mathrm{G}} 155.81$. The lowest $\mathrm{I}_{\mathrm{G}}$ average was film CH:PVA (40:60) with $\mathrm{I}_{\mathrm{G}}$ 135.67. The $I_{G}$ value was obtained from the average RGB value. The higher $I_{G}$ value indicates that the level of white colour was high, which means the colour was fading or tended to be transparent. The lower $\mathrm{I}_{\mathrm{G}}$ value 
indicates the level of black colour was high, which means the colour appearance was stronger (Hidayah et al., 2017).

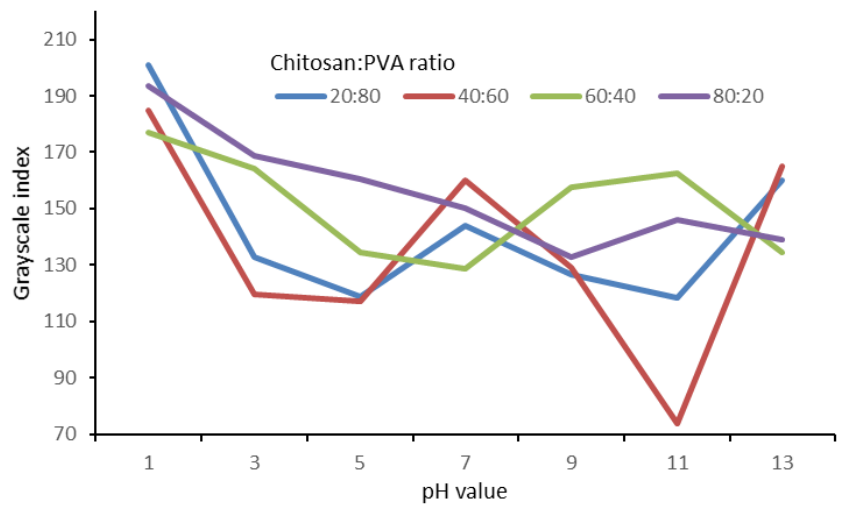

Figure 1. Grayscale index of film indicator with the various proportion of $\mathrm{CH}$ and PVA with the addition of BPFA extract at different $\mathrm{pH}$ values

The film CH:PVA (80:20) colour changes in various buffer $\mathrm{pH}$ were not very obvious due to the opaque yellowish film colour. The colour of the film CH:PVA (80:20) was influenced by the high $\mathrm{CH}$ ratio. The higher $\mathrm{CH}$ ratio affected the colour of the film becoming opaque and decreases the intensity of the colour changes (Ningrum et al., 2019).

The film CH:PVA (40:60) could show a significant colour change at any $\mathrm{pH}$ level. A low $\mathrm{I}_{\mathrm{G}}$ value of film CH:PVA (40:60) indicates a more intense colour than the others. It was influenced by the amount of BPFA that were trapped inside the PVA chains. On the other hand, the film CH:PVA (40:60) colour change was also related to the high total anthocyanin content. According to previous research by Zhai et al. (2017), the starch-PVA film with the addition of plasticizer was able to form a hydrogen bond with anthocyanin from rosella. Subsequently, the anthocyanins from rosella were trapped inside the polymer. The higher total anthocyanin content in a film could show clearer colour changes in a film in which the PVA ratio was more dominant. The PVA is a clear and transparent polymer which it does not display any colour that could sway the BPFA colour changes. Based on the previous study by Bonilla et al. (2014) that the film CH:PVA (30:70) displayed a transparent or white coloured film under the UV light transmission test compare to any other film.

A good indicator film can show a variety of vivid colour change when placed at different $\mathrm{pH}$. This function is the most important aspect of making the indicator film. The indicator film is required to be able to provide colour changes that can be seen by normal eyes. The main purpose of the application of film indicators in food packaging is to monitor the food quality through changes in $\mathrm{pH}$ without opening its packaging or giving any change to the product (Pourjavaher et al., 2017).

Despite the indicator film's ability to indicate food spoilage, the CH-PVA film has limitations in the application for dry products. The film needs direct contact with the food surface with enough water content to be absorbed into the polymer film. Moreover, the application of this film is preferable for a product that is kept in a chiller or freezer to avoid the damage of anthocyanin extract due to high temperature.

\section{Conclusion}

All films with various $\mathrm{CH}$ and PVA ratio can show colour changes in various $\mathrm{pH}$ ranges. However, the indicator film with the proportion of CH:PVA (40:60) can provide the clearest colour changes following its main purpose as an indicator film of $\mathrm{pH}$ change. The best result was found in the ratio of CH:PVA (40:60) with a thickness of $0.15 \mathrm{~mm}$, TS of $11.02 \mathrm{MPa}, \mathrm{E} \%$ of $48.00 \%$, and total anthocyanin of $25.08 \mathrm{mg} / \mathrm{g}$.

\section{Conflict of interest}

The authors declare no conflict of interest.

\section{Acknowledgements}

The authors would like to thank Diponegoro University for its financial support.

\section{References}

Abraham, A., Soloman, P.A. and Rejini, V.O. (2016). Preparation of Chitosan-Polyvinyl Alcohol Blends and Studies on Thermal and Mechanical Properties. Procedia Technology, 24, 741-748. https:// doi.org/10.1016/j.protcy.2016.05.206

Betz, M., Steiner, B., Schantz, M., Oidtmann, J., Mäder, K., Richling, E. and Kulozik, U. (2012). Antioxidant capacity of bilberry extract microencapsulated in whey protein hydrogels. Food Research International, 47(1), 51-57. https://doi.org/10.1016/ j.foodres.2012.01.010

Bonilla, J., Fortunati, E., Atarés, L., Chiralt, A. and Kenny, J.M. (2014). Physical, structural and antimicrobial properties of polyvinyl alcoholchitosan biodegradable films. Food Hydrocolloids, 35, 463-470. https://doi.org/10.1016/ j.foodhyd.2013.07.002

Choi, I., Lee, J.Y., Lacroix, M. and Han, J. (2017). Intelligent $\mathrm{pH}$ indicator film composed of agar/ potato starch and anthocyanin extracts from purple sweet potato. Food Chemistry, 218, 122-128. https:// doi.org/10.1016/j.foodchem.2016.09.050 
Damodaran, T., Tan, B.W.L., Liao, P., Ramanathan, S., Lim, G.K. and Hassan, Z. (2018). Clitoria ternatea L. root extract ameliorated the cognitive and hippocampal long-term potentiation deficits induced by chronic cerebral hypoperfusion in the rat. Journal of Ethnopharmacology, 224(1), 381-390. https:// doi.org/10.1016/j.jep.2018.06.020

El-Hefian, E.A., Nasef, M.M. and Yahaya, A.H. (2010). The preparation and characterization of Chitosan / Poly (Vinyl Alcohol) blended films. E-Journal of Chemistry, 7(4), 1212-1219. https:// doi.org/10.1155/2010/626235

Gomes, A.M.M., Da Silva, P.L., E Moura, C.D.L., Da Silva, C.E.M. and Ricardo, N.M.P.S. (2011). Study of the mechanical and biodegradable properties of cassava starch/chitosan/PVA blends. Macromolecular Symposia, 299-300(1), 1220-1226. https://doi.org/10.1002/masy.200900157

Hajji, S., Chaker, A., Jridi, M., Maalej, H., Jellouli, K., Boufi, S. and Nasri, M. (2016). Structural analysis, and antioxidant and antibacterial properties of chitosan-poly (vinyl alcohol) biodegradable films. Environmental Science and Pollution Research, 23 (15), 15310-15320. https://doi.org/10.1007/s11356016-6699-9

Halász, K. and Csóka, L. (2018). Black chokeberry (Aronia melanocarpa) pomace extract immobilized in chitosan for colourimetric $\mathrm{pH}$ indicator film application. Food Packaging and Shelf Life, 16, 185 -193. https://doi.org/10.1016/j.fps1.2018.03.002

Hidayah, N., Aji, M.P. and Sulhadi, S. (2017). Analisis citra pewarna alami dari ekstrak kulit buah naga (Hylocereus polyrhizus), Prosiding Seminar Nasional Fisika (E-Journal), 6, SNF2017-MPS. https:// doi.org/10.21009/03.SNF2017.02.MPS.13

Jirukkakul, N. (2013). A study of Mu yor sausage wraps using chitosan films incorporating garlic oil, lemon grass oil and galangal oil. International Food Research Journal, 20(3), 1199-1204.

Kang, S., Wang, H., Guo, M., Zhang, L., Chen, M., Jiang, S., Li, X. and Jiang, S. (2018). Ethylene-vinyl Alcohol Copolymer-Montmorillonite Multilayer Barrier Film Coated with Mulberry Anthocyanin for Freshness Monitoring. Journal of Agricultural and Food Chemistry, 66(50), 13268-13276. https:// doi.org/10.1021/acs.jafc.8b05189

Koosha, M. and Hamedi, S. (2019). Intelligent Chitosan/ PVA nanocomposite films containing black carrot anthocyanin and bentonite nanoclays with improved mechanical, thermal and antibacterial properties. Progress in Organic Coatings, 127, 338-347. https://doi.org/10.1016/j.porgcoat.2018.11.028
Kungsuwan, K., Singh, K., Phetkao, S. and Utama-ang, N. (2014). Effects of $\mathrm{pH}$ and anthocyanin concentration on colour and antioxidant activity of Clitoria ternatea extract. Food and Applied Bioscience Journal, 2(1), 31-46.

Kurek, M., Brachais, C.H., Nguimjeu, C.M., Bonnotte, A., Voilley, A., Galić, K., Couvercelle, J.P. and Debeaufort, F. (2012). Structure and thermal properties of a chitosan coated polyethylene bilayer film. Polymer Degradation and Stability, 97(8), 1232-1240. https://doi.org/10.1016/ j.polymdegradstab.2012.05.039

Kuswandi, B., Wicaksono, Y., Jayus, Abdullah, A., Heng, L.Y. and Ahmad, M. (2011). Smart packaging: Sensors for monitoring of food quality and safety. Sensing and Instrumentation for Food Quality and Safety, 5(3-4), 137-146. https:// doi.org/10.1007/s11694-011-9120-x

Luchese, C.L., Sperotto, N., Spada, J.C. and Tessaro, I.C. (2017). Effect of blueberry agro-industrial waste addition to corn starch-based films for the production of a pH-indicator film. International Journal of Biological Macromolecules, 104(Part A), 11-18. https://doi.org/10.1016/j.ijbiomac.2017.05.149

Ma, G., Yang, D., Su, D., Mu, X., Kennedy, J.F. and Nie, J. (2010). Preparation and properties of watersoluble chitosan and polyvinyl alcohol blend films as potential bone tissue engineering matrix. Polymers for Advanced Technologies, 21(3), 189-195. https:// doi.org/10.1002/pat.1415

Maciel, V.B.V., Yoshida, C.M.P. and Franco, T.T. (2015). Chitosan/pectin polyelectrolyte complex as a $\mathrm{pH}$ indicator. Carbohydrate Polymers, 132, 537545. https://doi.org/10.1016/j.carbpol.2015.06.047

Mittal, A., Garg, S., Kohli, D., Maiti, M., Jana, A.K. and Bajpai, S. (2016). Effect of cross linking of PVA/ starch and reinforcement of modified barley husk on the properties of composite films. Carbohydrate Polymers, 151, 926-938. https://doi.org/10.1016/ j.carbpol.2016.06.037

Munthoub, D.I. and Rahman, W.A.W.A. (2011). Tensile and water absorption properties of biodegradable composites derived from cassava skin/polyvinyl alcohol with glycerol as plasticizer. Sains Malaysiana, 40(7), 713-718.

Ningrum, E.O., Ardiani, L., Rohmah, N.A. and Fajar, N. (2019). Modifikasi biokomposit kitosan dari cangkang rajungan (Portunus Pelagicus) dan Pektin untuk aplikasi edible film, presented at Seminar Nasional Teknik Kimia “Kejuangan" Pengembangan Teknologi Kimia Untuk Pengolahan Sumber Daya Alam Indonesia, Yogyakarta, 2019. Yogyakarta, Jurusan Teknik Kimia, FTI, UPN "Veteran". [In 
Bahasa Indonesia].

Paes, J., Dotta, R., Barbero, G.F. and Martínez, J. (2014).

Extraction of phenolic compounds and anthocyanins from blueberry (Vaccinium myrtillus L.) residues using supercritical $\mathrm{CO}_{2}$ and pressurized liquids. Journal of Supercritical Fluids, 95, 8-16. https:// doi.org/10.1016/j.supflu.2014.07.025

Pereira, V.A., de Arruda, I.N.Q. and Stefani, R. (2015). Active chitosan/PVA films with anthocyanins from Brassica oleraceae (Red Cabbage) as TimeTemperature Indicators for application in intelligent food packaging. Food Hydrocolloids, 43, 180-188. https://doi.org/10.1016/j.foodhyd.2014.05.014

Phrueksanan, W., Yibchok-Anun, S. and Adisakwattana, S. (2014). Protection of Clitoria ternatea flower petal extract against free radicalinduced hemolysis and oxidative damage in canine erythrocytes. Research in Veterinary Science, 97(2), 357-363. https://doi.org/10.1016/j.rvsc.2014.08.010

Pourjavaher, S., Almasi, H., Meshkini, S., Pirsa, S. and Parandi, E. (2017). Development of a colourimetric $\mathrm{pH}$ indicator based on bacterial cellulose nanofibers and red cabbage (Brassica oleraceae) extract. Carbohydrate Polymers, 156, 193-201. https:// doi.org/10.1016/j.carbpol.2016.09.027

Pratama, Y., Abduh, S.B.M., Legowo, A.M. and Hintono, A. (2019). Effect of chitosan-palm olein emulsion incorporation on tapioca starch-based edible film properties. International Food Research Journal, 26(1), 203-208.

Saxena, A., Elder, T.J., Pan, S. and Ragauskas, A.J. (2009). Novel nanocellulosic xylan composite film. Composites Part B: Engineering, 40(8), 727-730. https://doi.org/10.1016/j.compositesb.2009.05.003

Wang, X., Yong, H., Gao, L., Li, L., Jin, M. and Liu, J. (2019). Preparation and characterization of antioxidant and $\mathrm{pH}$-sensitive films based on chitosan and black soybean seed coat extract. Food Hydrocolloids, 89, 56-66. https://doi.org/10.1016/ j.foodhyd.2018.10.019

Warsiki, E., Nofrida, R. and Yuliasih, I. (2013). The Use of Erpa (Aerva sanguinolenta) Leaf Extract as Colour Indicator Smart Label. Jurnal Ilmu Pertanian Indonesia, 18(1), 15-19.

Wei, Y.C., Cheng, C.H., Ho, Y.C., Tsai, M.L. and Mi, F.L. (2017). Active gellan gum/purple sweet potato composite films capable of monitoring $\mathrm{pH}$ variations. Food Hydrocolloids, 69, 491-502. https:// doi.org/10.1016/j.foodhyd.2017.03.010

Yoshida, C.M.P., Maciel, V.B.V., Mendonça, M.E.D. and Franco, T.T. (2014). Chitosan biobased and intelligent films: Monitoring $\mathrm{pH}$ variations. $L W T$ -
Food Science and Technology, 55(1), 83-89. https:// doi.org/10.1016/j.lwt.2013.09.015

Zhai, X., Shi, J., Zou, X., Wang, S., Jiang, C., Zhang, J., Huang, X., Zhang, W. and Holmes, M. (2017). Novel colourimetric films based on starch/polyvinyl alcohol incorporated with roselle anthocyanins for fish freshness monitoring. Food Hydrocolloids, 69, 308-317. j.foodhyd.2017.02.014 https://doi.org/10.1016/ 